\title{
TEKKE VE ZAVIYELER KANUNU ÇERÇEVESINDE ALEVÎLIKK-BEKTAŞîLIK*
}

Özet: Makalenin giriş kısmında, 677 Sayılı Tekke ve Zaviyeler Kanunu'nun mahiyeti ve söz konusu kanunun tarihsel arka planı ele alınmıştır. Birinci kısımda ise Alevîlik-Bektaşilik meselesinin kökenlerine değinilmiştir. Daha sonra, tekke ve zaviyelerin kapatılmasının ardından yaşanan gelişmeler ve ortaya çıkan durum üzerinde durulmuştur. Son olarak da, konuyla ilgili ortaya çıkan problemlere yönelik çözüm önerileri ve bunların olabilirlikleri üzerinde birtakım değerlendirmeler yapılmıştır.

Anahtar kelimeler: Tekke, zaviye, kanun, Alevilik, Bektaşilik, mezhep.

\section{The Alevism and Bektashism in the context of Dervish Lodges Law}

Abstract: In the introduction, legal nature of The Law of Dervish Lodges and Retreat with the law no 677 and its historical backround are examined. Then, in the first part, the roots of the Alevi-Bektashi creed is mentioned. In the second part, the emerging problems after the closure of dervish lodges and retreats and their results are discussed. Lastly various solutions for the problems are offered and the possibility of their success is evaluated.

Keywords: The law of the Dervish lodges, Alevism, Bektashism, sect.

\section{Giriş}

Tekke ve zaviyelerin kapatılması 30 Kasım 1925 yılında kabul edilen ve 13 Aralık 1925'te Resmi Gazete'de yayınlanan 677 sayılı kanunla uygulamaya konmuştur. Konuyla ilgili kanun maddeleri şu şekildedir: ${ }^{1}$

Madde 1 - Türkiye Cumhuriyeti dâhilinde gerek vakıf suretiyle, gerek mülk olarak şeyhinin tasarrufu altında, gerek diğer suretlerle tesis edilmiş bulunan bilumum tekkeler ve zaviyeler, sahiplerinin diğer şekilde temellük ve tasarruf hakları baki kalmak (yani başka maksatlar için kullanılmak) üzere kâmilen kapatılmışlardır. Bunlardan

* $\quad$ Bu metin Güncel Sorunlarıla II. Uluslararası Alevîlik ve Bektaşîlik Sempozyumu'da (16-18 Nisan 2014, Çanakkale ) sunduğum tebliğin geliştirilerek makale hâline getirilmiş şeklidir.

** Doç. Dr., Hitit Üniversitesi İlahiyat Fakültesi

1 Tekke ve zaviyelerle türbelerin kapatılmasına ve bunlarla ilgili türbedarlık (türbede hizmet edenler) gibi diğer birtakım unvanların men ve ilgasına dair kanun no: 677, Tarih: 13 Aralık 1925. 
mevzu usulü dâhilinde halen cami veya mescit olarak kullanılanlar ipka edilir.

Bilumum tarikatlarla, şeyhlik, dervişlik, müritlik, dedelik, seyitlik, çelebilik, babalık, emirlik, naiplik, halifelik, büyücülük, üfürükçülük, falcılık ve gaipten haber vermek ve murada kavuşturmak maksadıyla nüshacılık gibi unvan ve sıfatların istimaliyle, bu unvan ve sıfatlara ait hizmet ifa ve kisve iksâsı (elbise giyilmesi) memnudur. Türkiye Cumhuriyeti dâhilinde selâtine (padişahlara, sultanlara) ait veya bir tarikata (dini tarikata) veyahut cerri menfaate (çıkarcılığa) müstenit olanlarla bilumum sair türbeler mesdut (kapatılmış) ve türbedarlıklar mülgadır. Kapatılmış olan tekke ve zaviyeleri veya türbeleri açanlar veya bunları yeniden ihdas edenler veya tarikat âyini icrasına mahsus olarak velev muvakkaten olsa bile yer verenler ve yukarıdaki unvanları taşıyanlar veya bunlara mahsus hizmetleri ifa veya kıyafeti iksâ edenler üç aydan eksik olmamak üzere hapse ve elli liradan aşağı olmamak üzere para cezasına çarptırılırlar.

Madde 2 - İşbu kanun neşri tarihinden muteberdir.

Madde 3 - Bu kanunun icrasına Vekiller Heyeti memurdur. ${ }^{2}$

Tekke ve zaviyelerin söz konusu yasayla kapatılmasından önce Osmanlı' da başlatılan birtakım uygulamalar 1925 yılındaki bu sürecin hazırlayıcısı olmuştur. Osmanlı devlet yönetimi ilk adımını 1812 yılında atarak tekke vakıfları kendi kontrolüne almıştır. 1826 yılında Yeniçeri ocağını dağıtmış ve birkaçı hariç tüm Bektaşî tekkelerine kilit vurmuştur. Buraları kontrol etmek amacıyla yerlerine Nakşibendî ve Mevlevî şeyhlerini görevlendirmiştir. I. Abdülmecid döneminde (1839-1861) bazı tekke şeyhliklerinin Bektaşîlere verilmesi neticesinde kısmî bir yumuşama süreci yaşanmıştır. Bununla birlikte devlet, 1866 'da Şeyhülislamlığa bağlı olarak ulema ve tarikat şeyhlerinden oluşan Meclis-i Meşâyih kurumunu oluşturarak tüm tekkelerin yönetimini kendi sorumluluğuna almıştır. 1918 yılına gelindiğinde İstanbul-Taşra ayrımına gidilerek İstanbul'daki tekkeler Meclis-i Meşâyih, taşradakiler ise müftülerin başkanlığında oluşturulan Encümen-i Meşayih'in kontrolüne bırakılmıştır. Bu şekilde tekkeler hem mali hem de idari açıdan özerkliklerini kaybetmişlerdir.

Osmanlı yönetiminin tarikatların kontrolünü sağlamak amacıyla oluşturduğu bu yapı, Cumhuriyet döneminde yeniden şekillendirilmiştir. 1924 yılında Diyanet İşleri Başkanlığı'nın kurulması neticesinde cami ve mescitlerin yanında tekke ve zaviyelerin yönetimi de bu kuruma aktarılmıştır. 1925 tarihinde çıkarılan 677 sayılı "Tekke ve Zâviyelerle Türbelerin Seddine ve Türbedarlıklarla Birtakım Unvanların Men ve İlgasına Dair Kanun"la birlikte Türkiye'deki tekke ve zaviyelerin kapısına kilit vurulmuştur. Fakat 1 Mart

2 Düstur Tertip no: 3, cilt: 7, s. 113. 
1950 tarih ve 5566 sayılı kanunla birlikte 19 türbenin açılmasına izin verilmiştir. $^{3}$

\section{Alevîlik-Bektaşîlik Sorununun Tarihi Kökenleri}

Tekke ve zaviyelerin kapatılmasının Türkiye'deki toplum hayatında pek çok açıdan etkisi bulunmakla birlikte ben burada meselenin Alevîlik-Bektaşîlik boyutu üzerinde durmaya çalışacağım.

"Alevîlik" kavramının kastedilen gruplarla ilgili kullanımının 19. asrın sonlarında olduğu bilinmektedir. Hâlbuki Osmanlı döneminde daha ziyade "Kızılbaş" ismi öne çıkmaktaydı. "Kızılbaş" kavramı ilk dönemlerinde sadece Safevî taraftarlığı anlamına gelmekte olup sonraları bazı Osmanlı din adamlarını "mülhidlik" ve "kâfirlik" yakıştırmalarıyla farklı bir boyut kazanmıştır. Aslında Yavuz ve Şah İsmail'in siyasi mücadelesi olan bu mesele, bu tür karşılıklı ithamlarla Sünnîlik-Şiîlik çatışmasına dönüştürülmüştür. ${ }^{4}$

Söz konusu Kızılbaşların önemli bir kısmı Osmanlı-Safevî çatışmalarının durulmasından sonra Hacı Bektaş-1 Veli'nin dergâhı etrafında toplanarak "Bektaşî zaviyesi" adıyla devlet nezdinde meşruiyet elde etmişlerdir. Ancak zaman içerisinde devletle olan ilişkilerinde yaşamsal sorunun esas kaynağı olarak algılanmaları neticesinde, 1826 yılında Yeniçeriliğin ilgasıyla birlikte bu hukuki statü ve şemsiyelerini kaybetmişlerdir. Kısa bir süre sonra devletin göz yumması sonucu tekrar faaliyetlerine başlamakla birlikte 1925 yılındaki 677 sayılı yasa, tüm diğer benzeri yapılanmalar gibi onların da faaliyetlerine son vermelerine yol açmıştır.

Önce Kızılbaşlık sonra da Alevîlik-Bektaşilik olarak günümüze kadar

3 Mustafa Kara, "Tekke", DIA, c. 40, s. 370; Mustafa Kara, "Tasavvuf ve Tarikat", Tanzimattan Cumhuriyete Türkiye Ansiklopedisi, İstanbul 1985, c. IV, ss. 985-986; İlber Ortayl, İmparatorluğun En Uzun Yüzyıll, Timaş Yayınları, İstanbul 2008, ss. 158-159; Halil İbrahim Şimşek, "Türk Modernleşmesi Sürecinde Tasavvuf Alanında Ortaya Çıkan Bazı Yöntem Tartışmaları", Hitit Üniversitesi Illahiyat Fakültesi Dergisi, c. 5, sayı: 9, ss. 9-14, 32-34.

4 Hasan Onat, "Kızılbaşlık Farklılaşması Üzerine", İslam Mezhepleri Tarihi El Kitabı, Grafiker Yayınları, Ankara 2012, s. 569.

Hem Osmanlı hem de Safevî totaliter devletlerinin temel çatışma nedeni mezhep ayrılığı değildi. Her iki devlet de kendi siyasi ve askerî nüfuzlarını genişletmek amacındaydılar. $\mathrm{Bu}$ nedenle var olan mezhebî mirası kullanmaktan çekinmemişlerdir. Ahmed el-Kâtib, Nedenleri Tarihte Kalmış Siyasi Ayrılık, Sünnilik-Şiilik, İslam Birliği, çev.: Muharrem Tan, İstanbul 2009, s. 343. 
gelmiş bu problemin bir türlü çözülememiş olmasının tarihi süreç içerisinde etkili olmuş belli başlı nedenleri vardır. Mesela ilk aşamada Osmanlı'nın kurumsallaşmaya doğru ilerlediği süreçte hızla merkezileşmesi ifade edilen en önemli sebeplerin başında gelir. Kurumsallaşma ve merkezileşmeye paralel olarak Fatih Sultan Mehmet'teki serbest ve Hurufî meyilli din anlayışı Yavuz Selim'e gelince koyu Sünnî bir zihniyete dönüşmüştür. ${ }^{5}$

Osmanlılarla Safevî Devleti arasındaki mücadelede Kızılbaş zümrelerin konumu ise iç dinamiklerin yanında dışarıdan kaynaklı birtakım müdahalelerin de sorunun oluşumundaki etkisini gösterir. Yine dış kaynaklı olarak değerlendirebileceğimiz 'Türk kültürüne yabancı Batılılar tarafından başlatılan Alevîlik konusundaki çalışmalar' da dikkat dikkat çeken hususların başında yer alır. Alevîlik-Bektaşîlikle ilgili ilk akademik çalışmaların Batılı araştırmacılar tarafından yapılması, birtakım yapay farklılıkların öne çıkarılıp ortak sosyo-kültürel mirasın görmezden gelinmesine sebep olmuştur. Neticede Alevîlik-Bektaşilik konusu, birtakım etnik unsurların da devreye sokulmasıyla manipüle edilmiş ve siyasi-ideolojik bir araç haline dönüştürülmüştür. ${ }^{6}$

Osmanlı Devleti'nde Acem kaynaklı Safevilerle başlayan etkiler Kaçarlar döneminde devam etmiş, hatta 1925 yılında bir ulus-devlet olarak kurulan Pehlevilerle birlikte tekrar tazelenmiştir. İran Şah'ının Humeyni ve onun destekçisi ulemaya karşı gittikçe güç kaybetmesi onu geçmişte Safevîler ile Kaçarların başvurduğu malum tehlikeli oyuna başvurmaya yöneltmiştir. Şah, ulemanın dikkatlerini başka yöne çekebilmek amaciyla hedef olarak Türkiye'deki Alevî kesim ile Irak'taki Şiîleri seçmiştir. Anadolu'nun çeşitli bölgelerine gönderdikleri Şî̂ propagandistler, etkileyebildikleri insanları İran'ın Kum medreselerinde tahsile yönlendirmişlerdir. Bu tür faaliyetler özellikle 1960'lı yıllarda etkili olmuş ve Şiî tedrisatından geçirilen bir kısım Alevî Anadolu'ya dönerek Şiî fikirleri yaymaya başlamıştır.7 Neticede bu durum devletin dikkatinin tekrar bu kesim üzerinde yoğunlaşmasına neden olmuştur.

Alevîlik-Bektaşîlik meselesinin yukarıda ifade ettiğimiz birtakım nedenlerden dolayı farklı boyutlara taşınmış olması bir yana, ülkemizde demokra-

\footnotetext{
5 İlber Ortaylı, Gelenekten Geleceğe, Alkım Yayınları, İstanbul 2007, s. 52.

6 Onat, “Kızılbaşlık Farklılaşması Üzerine”, ss. 559-560.

7 Mehmet Saray, Türk-İran İlişkiler, Ankara 1999, s. 128.
} 
siye geçiş sürecinde yapılan birtakım müdahalelerin meseleyi daha da içinden çıkılmaz bir hale getirdiği bilinmektedir. 12 Eylül 1980 askeri darbesinin oluşumuna yol açan Komünizm-Milliyetçilik çatışmaları, özellikle zeminin uygun olduğu bölgelerde Alevî-Sünnî kutuplaşması ekseninde kurgulanmıştır. Alevîlerin neredeyse bir bütün olarak komünizm tarafında yer alması, çatışmanın bu boyuta taşınmasına kolaylık sağlamıştır. Gerçekte ise meselenin hem Alevîlik hem de Sünnîlikle bir ilgisi yoktu. Zira ne Alevî kesimin ne de Sünnîlerin kendi mezhepsel kimliklerini öne çıaran herhangi bir talepleri olmamıştır. Neticede solcu Alevî oluşumlar, anarşinin sorumluları "sosyalist militanlar" olarak 12 Eylül askeri darbesiyle birlikte bastırılmıştır. ${ }^{8}$

Yaklaşık 10 yıl sonra Sovyetler Birliği'nin dağılması, ardından tüm Doğu Bloku'nun çökmesi ve komünizmin birden bire tedavülden kalkması ise, sol ideolojiye mensup Alevîlerde yeni bir çalkantı meydana getirmiş ve bu kesim, hızlı bir şekilde dernek ve vakıf işlerine girişerek kendilerine yeni bir uğraşı alanı bulmuştur. ${ }^{9}$ Alevîler arasında son zamanlarda özellikle sağ siyasal iktidarlara karşı oluşan tepki, dışarıdan yapıldığı düşünülen birtakım müdahalelerle birleşerek bazı Alevîleri dînî-siyasî bir yapılanmaya doğru itmiştir. Bu şekilde dinî inançlardan ve köklerinden bağımsız ideolojik yeni bir Alevîlik biçimi ortaya çıkmaya başlamıştır. ${ }^{10}$

\section{Tekke ve Zaviyelerin Kapatılmasının Etkileri}

1925'te kabul edilen ve kısa bir süre sonra yürürlüğe giren 677 sayılı Tekke ve Zaviyeler Kanunu, Bektaşî tekkelerinin kapatılmasına karar vermekle birlikte mevcut şeyhlerinin yerlerinde oturmalarına müsaade etmişti. Buna rağmen söz konusu kesimin önemli bir kısmı ülkeden ayrılmak zorunda kalmıştır. Mesela bunlardan biri olan Salih Niyazi Baba yaşananlardan sonra kendilerinin bu makama layık olmadığını düşünüp dergâhı terk etmiştir. Ona göre dergâhların binaları kapatılabilirdi, ancak tasavvufun asıl yaşandığı yerler olan kalpler asla kapatılamayacaktı. Niyazi Baba yaptığı birtakım girişimler neticesinde tarikat faaliyetlerini serbestçe devam ettiremeyeceğini

8 Yasin Aktay, "Tarihi, Kültürel, Folklorik ve Aktüel Boyutlarıyla Alevilik”, http://turkoloji.cu.edu.tr/HALKBILIM/yasin_aktay_alevilik.pdf (Erişim: 10.10.2014)

9 Hüseyin Yılmaz, Alevî-Sünnî Diyaloğu, Sivas 2011, s. 169.

10 Krş. İsmail Engin, "Alevîliğin Muhtevası Boşaltılıyor", Radikal Gazetesi, 7 Temmuz 2007; Hüseyin Yılmaz, Alevî-Sünnî Diyaloğu, Sivas 2011, s.169. 
anlayınca diğer bazı babalarla birlikte Türkiye'den ayrılarak Tiran'a gitmiştir. ${ }^{11}$ Takkeciler Tekkesi şeyhi Bektaş Baba ve Kâzımiye Dergâhı şeyhi Selmân Cemâli Baba'da bu vb. sebeplerle Tiran'a gidenler arasındadır. Hatta Salih Niyazi Baba daha sonra Bektaşîliğin merkezini Arnavutluk'a taşımak

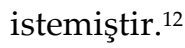

Yukarıda ifade edildiği gibi sözü edilen yasadan dolayı bir kısım Bektaşî dedesi ülkeyi terk etmek zorunda kalırken geri kalanları da yer altına çekilerek Alevîlik-Bektaşilik meselesinde yeni belirsizliklerin oluşumuna yol açmıştır. ${ }^{13}$

Her ne kadar bazılarına göre ${ }^{14}$ Alevîler tekke ve zaviyeler kanununu kendilerine veya dervişliğge yönelik bir kısıtlama olarak değil gericiliğe yönelik bir önlem olarak değerlendirmişse de devletin, tekke ve zaviyeler kanununu koyarak kendi belirlediği dışında herhangi bir dini söylem ve yapılanmaya müsaade etmediği rahatlıkla ifade edilebilir. ${ }^{15}$ Bu yüzden artık Bektaşî uygulamalarının (adetlerinin) çocuklu kadınlı hep birlikte evlerde düzenlenmeye başladığı görülmektedir. Yine bir ibadet biçimi olan Kızılbaşlık cemleri ise zamanla Mevlevîliktekine benzer bir gösteri aracı haline dönüşmüştür. ${ }^{16}$

677 sayılı yasa aslında toplumun bütün dini kesimleriyle alakalı olmakla birlikte, yasaklamanın muhatapları olan Sünnî ve Alevî grupların birbirlerinden farklı reaksiyon gösterdikleri görülmüştür. Değişik Sünnî gruplar mevcut dini yapılanmaları sayesinde faaliyetlerini yer altına kaydırarak eğitim ve öğretim faaliyetlerine devam etmişlerdir. Ancak Alevîler de Sünnîlere benzer şekilde kendi cemaatlerini ayakta tutacak gayri resmi dini

11 Şevki Koca, "Bektaşilik tarihinden notlar: Cumhuriyet'e doğru” (buradan sonra "Cumhuriyet'e doğru"),Cem, no. 92 (Ağustos 1999), ss. 54-58.

12 Hülya Küçük, "Cumhuriyet Döneminde Bektaşilik", Uluslar Arası Bektaşilik ve Alevilik Sempozyumu I, SDÜ İlahiyat Fakültesi, Isparta 2005, s. 76.

13 Hasan Onat, "Açılım Arayışlarının Gölgesinde Alevîlik-Bektaşîlik ve Kimlik Tartışmaları", Dini Araştırmalar, c. 12, sayı: 33, s. 45.

14 Mesela bk. Bedri Noyan Dedebaba, Bütün Yönleriyle Bektaşilik ve Alevilik, c. V, haz. Şakir Keçeli, Ankara 2002, s. 6.

15 Necdet Subaşı, "Resmi ve Gayri Resmi Din Söylemleri", Contemporary Perceptions of Islam in The Context of Science, Ethics and Art, International Symposium, 26-28 November 2010, Samsun, s. 254.

16 Hasan Onat, age, s. 44. 
müesseseler oluşturma gayreti içerisine girmemişlerdir. Bunun yerine, çocuklarını devletin açmış olduğu okullara göndermeyi tercih etmişlerdir. ${ }^{17}$ Söz konusu iki farklı durumun oluşmasında Alevîlerin Sünnî medreselere benzer güçlü kurumsal yapılara sahip olamamalarının önemli bir etkisi olsa gerektir.

Yukarıdaki ifadelerden yola çıkarak Cumhuriyet sonrası dönemde Alevîlik-Bektaşilik konularında yaşanan tüm gelişmeleri sadece bir yasaya bağlamak elbette gerçekçi olmaz. Burada da ifade ettiğimiz gibi hem dünyada yaşanan birtakım gelişmeler, hem de hızlı kentleşme gibi ülkemizde yaşanan bazı sosyo-politik gerçeklikler, meseleye yön veren diğer etmenler olmuştur.

Kentlerde oluşmaya başlayan Sünnî dindarlıktan endişelenen Alevîler, buna tepki olarak geleneksel Alevî inançlara yönelmeyi tercih etmemiş, aksine seküler bir Alevî kimliği oluşturma gayreti içine girmişlerdir. Bunun gerekçesi olarak da, eğitim kurumlarından yoksunluğun dışında, 'Modern Alevî kimliği oluşturma gayreti içerisinde olan kesimlerin, dini bireysel hayatının dışına çıkaran 1960-70'li yılların solcularından geliyor olması' olarak ifade edilir. ${ }^{18}$

Geleneksel Alevîlikte Allah-Muhammed-Ali hayatın her alanında kendini hissettirmekte olup gerek bireysel hayat, gerekse toplumsal yapı tamamen dini referanslar çerçevesinde yaşanıyordu. Ancak modern Alevîlikte durum farklılaşarak dini vurgular azalmış bunun yerine Alevî kimliği ve yeni oluşan bu Alevî kimliğe uygun bireyler yetiştirme gayreti ön plana çıkmıştır. Geleneksel dini kural ve kaidelerin yerine; mecburi din derslerinin kaldırılması, Madımak olayı, cemevlerinin statüsü ve köylere cami yapımının durdurulması gibi konularla ilgilenir olmuşlardır. ${ }^{19}$ Ancak Türk toplumunda 1990'lı yıllarda başlamış olan dine yönelim doğal olarak Alevîleri de etkilemiştir. Bu doğrultuda daha ziyade seküler kurumlar olarak inşa edilen

17 Aktay, "Tarihi, Kültürel, Folklorik ve Aktüel Boyutlarıyla Alevilik", http://turkoloji.cu.edu.tr/HALKBILIM/yasin_aktay_alevilik.pdf (Erişim: 10.10.2014)

18 Krş. Elise Massicard, Türkiye'den Avrupa'ya Alevi Hareketinin Siyasallaşması, İletişim Yayınları, İstanbul 2007, ss. 80-81; Rıza Yıldırım, "Geleneksel Alevilikten Modern Aleviliğe", Türk Kültürü ve Hacı Bektaş Veli Araştırma Dergisi, Ankara 2012, sayı: 62, s. 142.

19 Yıldırım, "Geleneksel Alevilikten Modern Aleviliğe", ss. 141-143. 
dernek ve vakıfların yerini cemevleri almaya başlamıştır. ${ }^{20}$

\section{Farklı Çözüm Önerileri}

Tekke ve zaviyeler, Alevîlerle Sünniler arasında önemli ortak paydalardan biri olan tasavvufun yaşandığı yerlerdi. Bunların kapatılmasının kitabî din anlayışı dışında bir nebze serbestlik sağlayan böyle önemli bir kaynaşma merciinin ortadan kalkmasına yol açtığı söylenebilir.

Ülkemizde Alevîlik meselesiyle ilgili ilk çözüm önerilerinden biri İttihat Terakki yöneticilerinden gelmiştir. İttihat Terakki ileri gelenleri Alevî olarak tanımladıkları grupların hepsi de Türk olduğu için ülkenin çok ihtiyacı olduğu bir dönemde onları da Türklük çatısı altına toplayarak birlik ve bütünlüğüne katkı sağlayacaklarını düşünüyorlardı. Kızılbaşlık adının halk nezdinde olumsuz birtakım çağrışımlara yol açmasından dolayı bunun yerine "Alevî" kavramını kullanıma sokmuşlardır. ${ }^{21}$

İlk olarak 1826' da Bektaşî tekkelerinin kapatılması ve sonrasında yaşanan gelişmeler, ardından İttihat Terakki'nin onlara yönelik söz konusu faaliyetleri, son olarak 1925 'te biri hariç tüm tekke ve zaviyelerin kapatılması pek çok açıdan olduğu gibi isim konusunda da birtakım karmaşa ve farklılıkların ortaya çıkmasına neden olmuştur. Ancak farklı bir yönüyle meseleye bakıldığında Bektaşîliğin "Alevîlik-Bektaşillk" şeklinde adlandırılmasının her iki kesim açısından da bir kısım avantajlar sağladığını düşünenler vardır. Bu görüşü savunanlara göre Kızılbaş Alevî olanlar bu şekilde etki alanlarını genişletmekte, Bektaşîler ise bir tarikat yapısı içermeyen "Alevîlik" ismi altında tekke ve zaviyeler yasağının kapsamı dışına çıkmaktadırlar. ${ }^{22}$

Meseleye diğer bir yönüyle bakıldığında ise kanun nedeniyle Bektaşîliğin bir tarikat olarak anılamaması bu kesimin kafa karışıklığını daha da artırmaktadır. Bu görüş sahiplerine göre; ister tarihi arka plan, ister oluşum şekli, isterse de kullanılan temel kavramlar açısından bakılsın, bu yapının

20 Rıza Yıldırım, “Cemevleri: Mevcut Durum ve Reform Yolu”, Türkiye'nin Demokratikleşmesi ve Alevi Talepleri Tespit ve Öneri Raporu, Liberal Düşünce Topluluğu, Ankara, 25 Ocak 2014, s. 8.

21 Onat, “Kızılbaşlık Farklılaşması Üzerine”, ss. 123-124.

22 Hülya Küçük, "Cumhuriyet Döneminde Bektaşilik", Uluslararası Bektaşilik ve Alevilik Seтроzуuти I, SDÜ İlahiyat Fakültesi, Isparta 2005, s. 79. 
tamamen tasavvufi bir oluşum olduğu rahatlıkla fark edilmektedir. ${ }^{23}$

Alevîlik-Bektaşîlik meselesiyle ilgili en önemli değişim parametrelerinden biri tekke ve zaviyelerin kapatılmasıyla ilgili kanun olduğu için çözüm önerilerinin büyük bir kısmı söz konusu yasanın kaldırılmasına endekslenmekte ve bu şekilde aslında film bir yönüyle geriye doğru sarılmaktadır. Bundan dolayı konuyla ilgili çözüm üreten bir kısım araştırmacıya göre günümüz Alevîliğinin devletle barışık, toplumun genel katmanları tarafından mutedil kabul edilebilecek ve asimilasyona maruz kalmadan Sünnîlerle uyum içerisinde yaşayabilecek bir teoloji üretmesi, ancak cemevlerinin yasal bir statüye kavuşturulmasıla mümkün olacaktır. ${ }^{24}$ Cemevleri, söz konusu kanunun yürürlükten kaldırılması ve hukuki bir statüye kavuşturulması neticesinde Alevî-Bektaşîliğin öğretildiği merkezler olarak hizmet göreceklerdir. Aksi durumda ise bu yerler, tepkisel mekânlar olarak Alevîlerin İslam'dan hızla uzaklaşmalarına sebep olacaktır. ${ }^{25}$

Meselenin diğer bir yönü ekonomik boyuttur. Zira cemevleri veya dergâhlar dernek veya vakıf kapsamında açıldıkları için mevcut yasalar çerçevesinde Diyanet İşleri Başkanlığı'ndan destek alamamaktadırlar. ${ }^{26} 677$ sayılı yasa ve diğer ilgili kanunlarda yapılacak düzenlemelerle bu sorun da aşılmış olacaktır.

Aslında günümüz şartları göz önünde bulundurulduğunda tarikat, cemaat vb. resmi olmayan birtakım dini oluşumların söz konusu yasa dolayısıyla faaliyetlerini gerçekleştiremediğini söylemek artık biraz zor olsa gerektir. Bu yüzden bazı devlet yetkilileri, hazırladıkları yeni anayasa taslağıyla 667 sayılı kanunu kaldırarak cemevlerinin hukuki bir statüye kavuşturulacağını çok rahat bir şekilde ifade etmektedirler.

Yine bu çerçevede "cemevlerinin tarihi bir geçmişi olmadığı için onlara yasal bir statü kazandırılmaz" şeklindeki bir anlayışın Alevî-Sünnî ilişkileri açısından pek yapıcı olmadığını ifade eden görüşler de vardır. Bu iddia sahiplerine göre cemevlerinin yasal bir statüye kavuşturulması için onları illa-

23 Hasan Onat, “Kimlik-Teoloji İlişkisi Bağlamında Alevilik-Bektaşilikle İlgili Kimlik Tartışmaları Üzerine", Alevilik-Bektaşilik Araştırmaları Dergisi, sayı: 1, s. 25.

24 Yıldırım, “Cemevleri: Mevcut Durum ve Reform Yolu”, s. 9.

25 Şenol Kulaç, "Mevcut Durum ve Reform Yolu”, Türkiye'nin Demokratikleşmesi ve Alevi Talepleri Tespit ve Öneri Raporu, Liberal Düşünce Topluluğu, Ankara, 25 Ocak 2014, s. 21.

26 Sönmez Kutlu, Alevîlik-Bektaşîlik Yazıları, Ankara 2006, s. 86. 
ki ibadethane statüsünde değerlendirmek gerekmemektedir. Zaten cemevleri kendine özgü bir konuma sahiptir. Bu durum hem geleneksel uygulamalara uygun olmakta hem de Alevî olsun olmasın halkın önemli bir kesimi tarafından kabul görmektedir. Din özgürlügünden bahsedebilmek için üst kimliklerin yanında Alevî, Sünnî ve Caferî gibi alt kimliklerin de dikkate alınması daha önemlidir. Türkiye'de Alevîler ile Sünnîler arasında en güçlü bağ olarak da, "ortak vatandaşlık paydası" ${ }^{27}$ kabul edilebilir makul bir durumdur.

Buraya kadar ifade edilenlerden de anlaşılacağı üzere sorunun asılının halen yürürlükte olan tekke ve zaviyeler kanunundan kaynaklandığg genellikle kabul görmektedir. Bununla birlikte çözümün tamamen tekke ve zaviyelerin yasal bir zemine oturtulmasına endekslenmesinin de doğru olmad1ğını belirtmemiz gerekir. Örneğin mevcut yasal şartlarda bile AlevîBektaşîlerin, müdahalelere maruz kalmadan, hatta bizzat desteklenmek suretiyle kendi özgün teolojik yapılarını oluşturmalarına fırsat tanınması ayrıca üzerinde durulması gereken önemli bir husustur. Tersi bir durum ise hiçbir kesime fayda sağlamamaktadır. Keza aksi durumda olabileceklerle ilgili İslam dünyasında değişik örnekler mevcuttur.

İslam dünyasında son iki-üç asırda ortaya çıkan ve içerisinde bulunduğu toplum ve inancıyla bağlarını kopartan iki önemli hareket vardır. Bunlardan biri Bahailik, diğeri ise Kadiyanilik'tir. Bahailik, İran'da Şiîlik içerisinde ortaya çımış ve zamanla Şia'yla, hatta İslâm diniyle irtibatını kopartarak ayrı bir din haline gelmiş bir harekettir. Kadiyanilik/Ahmediye cemaati ise, Sünnî Hind bölgesi Müslümanları arasında oluşan ve İslam içerisinde kalmakla birlikte kurucu liderini mehdi ve nebi olarak görüp, cami ve cemaatini, bulunduğu topluluktan ayıran diğer önemli bir harekettir.

Gerek Bahailik olsun gerekse Kadiyanilik, toplumsal yapıları ve teşekkül şartları pek çok açıdan farklılık içermekle birlikte içinde bulundukları toplum ve siyasetle olan ilişkilerinin, oluşumlarında benzer etkilere yol açtığını rahatlıkla ifade edebiliriz. Bahailer, henüz Bâbî hareketi olarak bilindiği dönemde Şiî ulemanın siyasal yönetimle ittifakı sonucunda kovuşturmaya uğramış, hatta başta liderleri olmak üzere ileri gelenleri idam edilmiştir. Yaşanan bu olaylar, beraberinde kopuşu getirmiş ve düzenledikleri bir top-

27 Hüseyin Yılmaz, Alevî-Sünnî Diyaloğu, Sivas 2011, ss. 86, 202, 206, 237, 291. 
lantıyla İslâm'dan ayrıldıklarını açıkça ilan etmişlerdir. ${ }^{28}$

Kadiyaniler veya diğer adıyla Ahmediye Cemaati ise özellikle Pakistan parlamentosunun kendilerini İslam dışı ilan etmesinin ardından camilerini ayırmışlardır. Onlar bu şekilde zaten oluşmaya başlayan mehdilik ve nübüvvet eksenli teolojik farklılaşmalarının yanında sosyolojik anlamda da içinde bulundukları toplumdan kopmaya başlamışlardır. ${ }^{29}$

Yukarıda verdiğimiz iki örnekten yola çıkarak benzer sürecin AlevîlikBektaşîlik açısından söz konusu olabileceği sorunun gidişatından anlaşılmaktadır. Üstelik Kadiyanilik ve Bahailik hareketlerinde uluslararası bağlantılar malumken Avrupa'da birtakım ülkelerin bu konuya el atmaları var olan endişeleri daha da artırmaktadır.

Alevîliğin veya Türkiye'deki farklı Alevî kesimlerin sistematik teolojik bir yapıya sahip olmaması, çoğunluğu yabancı kaynaklı değişik kesim ve ideolojilerin ilgilerini bu yöne çevirmelerine yol açmaktadır. Hâlihazırda çalkantılar yaşayan Alevîlerin köklerinden tamamen kopmamak için acil olarak yapmaları gereken şeylerden biri özlerine uygun kendi kurumsal yapılarını oluşturmalarıdır. Aksi takdirde her ne kadar Hasan Onat'ın "Alevîlik-Bektaşîliğin tarihsel gerçekliği ve özünde mevcut teolojik ilkelerle örtüşmeyen inşa faaliyetleri tarihin çöplüğüne gitmeye mahkûmdur" 30 ifadesi bir gerçekliği ifade etse de yine de meselenin söz konusu yapılara benzer oluşum riskleri taşıdığını ifade etmemiz gerekmektedir.

Alevîlik-Bektaşîliğin gerek dışarıdan olsun gerekse içeriden kendi dışındakiler veya siyaset aracılığıyla biçimlendirilmesinin sakıncaları büyük oranda kabul görmüştür. Özellikle iletişimin bu kadar yaygınlaştığı bir dönemde zorla asimilasyon çabaları tepkiyle karşılanmaktadır. Mesela Batı'nın birtakım Doğu Hıristiyanlarıyla yaşadıkları tecrübe bu duruma bir örnektir. Batılı Katolik ve Protestan kiliseler misyonerlik faaliyetleri çerçevesinde özellikle tarihi monofizit Hıristiyanları kendi mezheplerine kazandırmaya çalışıyorlardı. Ancak bu politikalarının aksi tesirlere yol açıp söz konusu kesimlerin İslâm'a geçtiklerini fark etmişlerdir. Bundan dolayı 1960'lardan

28 Cevad Meşkûr, Mezhepler Tarihi Sözlüğ̈̈, çev.: Mahfuz Söylemez, Mehmet Ümit, Cemil Hakyemez, Ankara Okulu Yayınları, Ankara 2011, ss. 62-70.

29 E. Ruhi Fığlalı, Günümüz İslam Mezhepleri, İzmir 2008, s. 467 vd.

30 Onat, "Kimlik-Teoloji İlişkisi Bağlamında Alevilik-Bektaşilikle İlgili Kimlik Tartışmaları Üzerine", s. 29. 
itibaren politika değiştirerek bu faaliyetlerinden vaz geçmişler ve onları Müslümanlara karşı desteklemeye başlamışlardır. ${ }^{31}$

Aslında günümüz Türk toplumundaki din anlayışının temellerine gidildiğinde farklılıklara hoşgörüyle yaklaşan bir yapı karşımıza çıkar. Ebu Hanife ve oluşum sürecindeki Hanefîliğin yani Mürcie'nin alışılmışın dişındaki din anlayışlarına sempatiyle bakan ve İslâmlaşma yönünde tedrîcîliği benimsediği için farklı unsurları kucaklayıcı yapısıyla öne çıkan bir akım olduğu bilinmektedir. Fakat kurumsallaşmasının ardından genelde iktidarların din anlayışlarında merkezi bir yer edinmesi ve fıkhî yönüyle öne çıan bir yapıya dönüşmesinden sonra bu özelliğini önemli ölçüde kaybetmiştir. Bu yönüyle Hanefîlik sıra dişı unsurların içerisinde temsil edildiği bir yapı olma özelliğini elinde tutamamıştır. Bu yüzden İbn Kemal ve Ebu's-Suud Efendi gibiler de birer Hanefî âlimi olmakla birlikte onların Ehl-i Sünnet dışı oluşumlara karşı tavrı daha ziyade reaksiyoner ve Selefî bir üslup içermiştir. ${ }^{32}$ Devletin din politikalarında esas alacağı bu tür bir Hanefîliğin Alevîlik benzeri oluşumlarla yan yana yaşayamayacağ ${ }_{1}$ sıklıkla hatırlanmalıdır. ${ }^{33}$

31 Ekrem Sarıkçıŏlu, Uluslararası Bektaşilik ve Alevilik Sempozyumu I, SDÜ İlahiyat Fakültesi, Isparta 2005, s. 6.

32 Klasik 73 fırka geleneğine bağlı kalan İbn Kemal; Haricîler, Rafızîler, Mürcie, Cehmiyye, Kaderiyye ve Cebriyye olarak isimlendirdiği ana fırkaları cehenneme gidecek bid'atçı sapık gruplar olarak değerlendirir. Bunların dışında kalan Ehl-i Sünnet'i ise kurtuluşa erecek fırka, fırka-i nâciye olarak nitelendirir. İbn Kemal, Risale fî Beyân-ı Fırak-ı Dâlle, Süleymaniye Kütüphanesi, Laleli, no: 3711, vr. 114b.

Diğer bir risalesinde İbn Kemal klâsik Mezhepler Tarihi tasnif geleneklerine bağlı kalmakla birlikte, güncel koşullara da riayet ederek Rafızîlerin içerisine "Aleviyye" isimli yeni bir grup ilave etmiştir. On göre bu kişiler, Hz. Ali'nin peygamberliğini iddia edenlerdir. İbn Kemal, Risale Fî Beyân-ı Fırakıı Dâlle, Süleymaniye Kütüphanesi, Laleli, no: 3711, vr. 114b.

33 Meseleye diğer bir yönüyle, yani ortak payda açısından bakıldığında ise daha müspet sonuçlar elde edilebilir. Hanefi mezhebinin kurucusu Ebu Hanife'nin, Zeyd b. Ali ve Cafer Sadık başta olmak üzere Ehl-i Beyt'e karşı olan sevgisinden dolayı Alevî-Bektaşî geleneği içerisinde saygın bir konuma sahip olduğu bilinmektedir. Yine Bektaşîliğin "iman" konusundaki yaklaşımları, büyük ölçüde Hanefî-Maturîdî geleneğin bir ürünüdür. Baba İlyas'ın halifelerinden olan Şeyh Edebali'nin, Alevîler arasında okunan bazı Cenknâmelerin yazarı olan Tursun Fakı'nın ve daha sonra Şeyh Bedreddin'in aynı zamanda birer Hanefî fakihi olmaları, ortak kültürel mirası doğrulayan unsurlardır. Ayrıca Hacı Bektaş-i Veli'nin, namazla ilgili vermiş olduğu bilgilerde Hanefî mezhebini esas almış olduğu malumdur. Bununla birlikte 19. asırda kaleme alınan bazı el yazmalarına bakıldığında Bektaşîlerin, kendilerini Caferî mezhebinden saydıkları görülür. Ancak onların bu tercihleri bilinçli olmayıp tepkisel bir tutumu yansıtmaktadır. Bu yüzden onların Caferîlik olarak algıladıkları, daha ziyade tasavvufî bir ekol veya bir tarikat yapılanması olan Bek- 


\section{Sonuç}

Tüm buraya kadar ifade ettiklerimizden anlaşılacağı üzere hangi açıdan bakarsak bakalım 677 sayılı yasanın artık günümüzde bir fayda sağlamamanın yanında özellikle Alevîlik-Bektaşîlik açısından ciddi sıkıntılara yol açtığını rahatlıkla ifade edebiliriz. Ancak bazı çevrelerin meseleyi AİHM'e taşıyarak Alevîliği farklı din olarak tanıtmaya çalışmaları sorunu çözmemekte, hatta meselenin makul bir ortamda tartışılmasına engel olmaktadır. Zira İslam dünyasında özellikle son üç asırda meydana gelen oluşumlarda dışarıdan kaynaklı etkilerin yoğunluk kazandığı ve bunun yeni sorundan başka bir getirisinin olmadığı bilinmektedir. Bu yüzden vaziyet, çözmek bir yana yüzyıllar içerisinde bu güne kadar çoğaltarak taşıdığımız bu sorunun ancak kendi gayretlerimizle üstesinden geleceğimizi göstermektedir. Devletlerin görmezlikten gelerek veya ülkenin dişına çıkartarak bastırmaya çalıştıkları başkaldırılar daha büyük sorunlar olarak tekrar kendilerine yöneltilmiştir. Bahailer, Kadiyaniler ve hatta İslam dışı Alevîlik yapılanmaları da bunu göstermektedir. Şayet durum böyle devam ederse, bırakalım Alevîlik meselesini çözmeyi, sisteme uymuyor diye ülkemizden sanki gizli bir elle kaçırtılan başka kişi ve grupların yol açtığı yeni sorunlarla karşı karşıya kalacağız demektir.

\section{Kaynakça}

Aktay, Yasin, "Tarihi, Kültürel, Folklorik ve Aktüel Boyutlarıyla Alevîlik”, http://turkoloji.cu.edu.tr/HALKBILIM/yasin_aktay_Alevîlik.pdf (Erişim: 10.10.2014)

el-Kâtib, Ahmed, Nedenleri Tarihte Kalmış Siyasi Ayrılık, Sünnilik-Şiilik, İslam Birliği, Türkçesi. Muharrem Tan, İstanbul 2009, s. 343.

Engin, İsmail, “Alevîliğin Muhtevası Boşaltılıyor, Radikal Gazetesi, 7 Temmuz 2007.

Fığlalı, E. Ruhi, Günümüz İslam Mezhepleri, İzmir 2008.

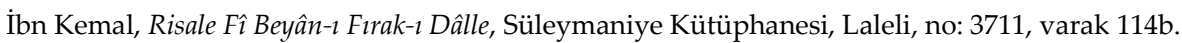

Kara, Mustafa, "Tasavvuf ve Tarikat”, Tanzimattan Cumhuriyete Türkiye Ansiklopedisi, İstanbul 1985, c. IV.

“Tekke", DIA, c. 40 , s. 370

taşîlik'tir. Fıkıhta Caferîliği takip ettikleri söylenemez. Abdest almak vb. mezhebi farklılıkların öne çıktığı ibadet biçimlerinde bunu gözlemlemek mümkündür. Mesela abdest alırken Caferîler gibi ayaklarını mesh etmeyip yıkamaktadırlar. On ki imamı dînî-siyasî liderleri olarak değil mistik önderler olarak kabul ederler. Sönmez Kutlu, “Aleviliğin Dini Statüsü", İslam Mezhepleri Tarihi El Kitabı, Grafiker Yayınları, Ankara 2012, ss. 588-595; Yılmaz Soyyer, 19. Yüzyılda Bektaşîlik, İstanbul 2012, ss. 115-123. 
Koca, Şevki, “Bektaşîlik Tarihinden Notlar. Cumhuriyet'e Doğru” (buradan sonra "Cumhuriyet'e doğru"),Cem, no. 92 (Ağustos 1999).

Kulaç, Şenol, "Mevcut Durum ve Reform Yolu”, Türkiye'nin Demokratikleşmesi ve Alevî Talepleri Tespit ve Öneri Raporu, Liberal Düşünce Topluluğu, Ankara 25 Ocak 2014.

Kutlu, Sönmez, "Alevîliğin Dini Statüsü", İslam Mezhepleri Tarihi El Kitabı, Grafiker Yayınları, Ankara 2012.

-------, Alevîlik-Bektaşîlik Yazıları, Ankara 2006.

Küçük, Hülya, "Cumhuriyet Döneminde Bektaşîlik", Uluslar Arası Bektaşîlik ve Alevîlik Sempozyumu I, SDÜ İlahiyat Fakültesi, Isparta 2005.

Massicard, Elise, Türkiye'den Avrupa'ya Alevî Hareketinin Siyasallaşması, İletişim Yayınları, İstanbul 2007.

Meşkûr, Muhammed Cevad, Mezhepler Tarihi Sözlüğ̈̈, çev.: Mahfuz Söylemez, Mehmet Ümit, Cemil Hakyemez, Ankara Okulu Yayınları, Ankara 2011.

Noyan, Dedebaba Bedri, Bütün Yönleriyle Bektaşîlik ve Alevîlik, c. V, haz.: Şakir Keçeli, Ankara 2002.

Onat, Hasan, "Açılım Arayışlarının Gölgesinde Alevîlik-Bektaşîlik ve Kimlik Tartışmaları", Dini Araştırmalar, c. 12, sayı: 33.

-, "Kızılbaşlık Farklılaşması Üzerine”, İslam Mezhepleri Tarihi El Kitabı, Grafiker Yayınları, Ankara 2012.

--------, “Kimlik-Teoloji İlişkisi Bağlamında Alevîlik-Bektaşîlikle İlgili Kimlik Tartışmaları Üzerine", Alevîlik-Bektaşîlik Araştırmaları Dergisi, sayı: 1.

Ortaylı, İlber, Gelenekten Geleceğe, Alkım Yayınları, İstanbul 2007.

-------, Imparatorluğun En Uzun Yüzyılı, Timaş Yayınları, İstanbul 2008.

Saray, Mehmet, Türk-İran İlişkileri, Ankara 1999.

Sarıkçıŏlu, Ekrem, Uluslararası Bektaşîlik ve Alevîlik Sempozyumu I, SDÜ İlahiyat Fakültesi, Isparta 2005.

Soyyer, Yılmaz, 19. Yüzyılda Bektaşîlik, İstanbul 2012.

Subaşı, Necdet, "Resmi ve Gayri Resmi Din Söylemleri", Contemporary Perceptions of Islam in The Context of Science, Ethics and Art, International Symposium, Samsun 26-28 November 2010.

Şimşek, Halil İbrahim, “Türk Modernleşmesi Sürecinde Tasavvuf Alanında Ortaya Çıkan Bazı Yöntem Tartışmaları", Hitit Üniversitesi İlahiyat Fakültesi Dergisi, c. 5, sayı: 9, ss. 7-40.

Yıldırım, Rıza, "Cemevleri”, "Mevcut Durum ve Reform Yolu”, Türkiye'nin Demokratikleşmesi ve Alevî Talepleri Tespit ve Öneri Raporu, Liberal Düşünce Topluluğu, Ankara, 25 Ocak 2014.

-------, “Geleneksel Alevîlikten Modern Alevîliğe, Türk Kültürü ve Hacı Bektaş Veli Araştırma Dergisi, 2012/62.

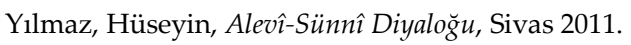

